Nama : Hasniar

Nim : 90100118042

Kelas : Ekonomi Islam A

\title{
SISTEM EKONOMI KAPITALISME
}

Kapitalisme dari segi etimologi, berasal dari dua kata Capital (modal) dan isme (paham atau cara pandang) sedangkan menurut istilah Kapitalisme adalah sistem perekonomian yang memberikan kebebasan secara penuh kepada setiap orang untuk melaksanakan kegiatan perekonomian seperti memproduksi barang, manjual barang, menyalurkan barang dan lain sebagainya. Dalam sistem ini pemerintah bisa turut ambil bagian untuk memastikan kelancaran dan keberlangsungan kegiatan perekonomian yang berjalan, tetapi bisa juga pemerintah tidak ikut campur dalam ekonomi $^{1}$

Konsep ekonomi kapitalis adalah suatu sistem yang memberikan kebebasan yang seluas-luasnya kepada individu untuk melakukan perekonomian. Konsep ini adalah hasil dari pemikiran Adam Smith seorang tokoh mazhab klasik dimana para ahli ekonomi dunia menilai bahwa pemikiran mazhab klasik merupakan dasar dari sistem ekonomi kapitalis. Adam Smith dalam teorinya menghendaki setiap orang diberi kebebasan untuk berusaha dalam persaingan yang sempurna ${ }^{2}$

Dalam ekonomi kapitalis, pasar memainkan peranan yang sangat penting dalam sistem perekonomian. Ekonomi kapitalis menghendaki pasar bebas untuk menyelesaikan permasalahan ekonomi, mulai dari produksi, konsumsi dan distribusi. Perilaku kapitalis adalah lassez faire et laissez le monde va de lui meme (biarkan ia berbuat dan biarkan ia berjalan, dunia akan mengurus diri sendiri). Maksudnya

1 Azhar "Antara Ekonomi Islam Dan Ekonomi Konvensional." Islamika: Jurnal Ilmu-Ilmu Keislaman 17(2), 2017. Hal 5.

${ }^{2}$ Hasan, Zainol, and Mahyudi Mahyudi.. “Analisis Terhadap Pemikiran Ekonomi Kapitalisme Adam Smith.” Istidlal: Jurnal Ekonomi dan Hukum Islam 4(1), 2020. Hal 33 
biarkan sajalah perekonomian berjalan dengan wajar tanpa intervensi pemerintah, nanti akan ada suatu tangan tak terlihat (invisible hands) yang akan membawa perekonomian tersebut ke arah keseimbangan ${ }^{3}$

Adapun ciri-ciri sistem kapitalis diantaranya :

a) Kebebasan memiliki harta secara perorangan

Hak milik perorangan merupakan elemen penting kapitalisme. Dalam paham kapitalisme tidak berlaku istilah hak milik berfungsi sosial. Pemberian hak milik secara mutlak akan menciptakan perilaku individu untuk menggunakan semaksimal mungkin sumber daya yang dimiliki dan berdampak pada distribusi pendapatan masyarakat.

b) Kebebasan ekonomi dan persaingan bebas

Setiap individu berhak untuk mendirikan, mengorganisasi dan mengelola perusahaan yang diinginkan. Individu juga berhak terjun dalam semua bidang perniagaan dan memperolah keuntungan sebanyak-banyaknya. Negara tidak boleh campur tangan dalam semua kegiatan ekonomi dan persaingan bebas yang berorientasi mencari keuntungan. Persaingan bisa terjadi antar produsen dalam menghasilkan produk, antar penyalur produk, antar karyawan untuk mendapatkan pekerjaan, bahkan antar pemilik modal, dan seterusnya.

c) Mementingkan diri sendiri.

Adam Smith mengatakan "Bukan berkat kemurahan hati tukang daging,tukang pembuat bir dan tukang roti kita dapat makan siang, akan tetapi karena mereka memperhatikan kepentingan pribadi mereka. Kita bicarakan bukan kepada rasa kemanusiaan mereka melainkan cinta mereka kepada diri mereka sendiri”

d) Perekonomian diatur oleh mekanisme pasar

\footnotetext{
${ }^{3}$ Parakkasi, Idris, And Kamiruddin Kamiruddin. "Analisis Harga Dan Mekanisme Pasar Dalam Perspektif Islam." Laa Maisyir: Jurnal Ekonomi Islam 5.1, 2018. Hal 108.
} 
Setiap harga barang yang ada dipasar sudah ditentukan oleh permintaan dan penawaran yang dilakukan secara bebas

e) Manusia dipandang sebagai mahluk homo-economicus, yang selalu mengejar kepentingan (keuntungan) sendiri ${ }^{4}$

f) Campur tangan pemerintah minimum

Dalam sistem ekonomi kapitalis, yang sangat berperan adalah individu, bukan pemerintah. Pihak Pemerintah memberikan kebebasan kepada para pemodal untuk mengembangkan usahanya Pemerintah tugasnya membuat regulasi untuk membayar pajak yang besar. Hasil dari pajak itulah digunakan untuk mensejahterakan rakyatnya Dengan kata lain, bahwa dalam sistem ini pemerintah bisa turut ambil bagian untuk memastikan kelancaran dan keberlangsungan kegiatan perekonomian yang berjalan, tetapi bisa juga pemerintah tidak ikut campur dalam ekonomi. ${ }^{5}$

Dampak positif sistem ekonomi kapitalis, antara lain adalah:

a) Mendorong aktifitas ekonomi secara signifikan

b) Persaingan bebas akan mewujudkan produksi dan harga ke tingkat wajar dan rasional

c) Mendorong motivasi pelaku ekonomi mencapai prestasi terbaik

Dampak negatif sistem ekonomi kapitalis, antara lain adalah:

a) terjadinya penumpukan harta dan distribusi kekayaan tidak merata

b) individualisme

c) distorsi pada nilai-nilai moral

d) pertentangan antar kelas, misalnya majikan dan buruh $^{6}$

${ }^{4}$ Mujiatun, Siti "Peran Pemerintah Tentang Pengembangan Perekonomian Dalam Perspektif Sistem Ekonomi Kapitalis, Sosialis, Dan Islam.” Jurnal Analytica Islamica/ 2014. Hal 96.

${ }^{5}$ Syamsul Effendi“"Perbandingan Sistem Ekonomi Islam Dengan Sistem Ekonomi Kapitalis Dan Sosialis." JRAM (Jurnal Riset Akuntansi Multiparadigma) 6(2). 2019. Hal 149

${ }^{6}$ Azhar. "Antara Ekonomi Islam Dan Ekonomi Konvensional.” Islamika: Jurnal Ilmu-Ilmu Keislaman 17(2), 2017. Hal 8. 


\section{DAFTAR PUSTAKA}

Azhar, Azhar. 2017. “Antara Ekonomi Islam Dan Ekonomi Konvensional.” Islamika: Jurnal Ilmu-Ilmu Keislaman 17(2): 1-16.

Hasan, Zainol, and Mahyudi Mahyudi. 2020. “Analisis Terhadap Pemikiran Ekonomi Kapitalisme Adam Smith." Istidlal: Jurnal Ekonomi dan Hukum Islam 4(1): 24-34.

Mujiatun, Siti. 2014. "Peran Pemerintah Tentang Pengembangan Perekonomian Dalam Perspektif Sistem Ekonomi Kapitalis, Sosialis, Dan Islam.” Jurnal Analytica Islamica 3: 90-107

Effendi, Syamsul. 2019. "Perbandingan Sistem Ekonomi Islam Dengan Sistem Ekonomi Kapitalis Dan Sosialis."JRAM (Jurnal Riset Akuntansi Multiparadigma) 6(2): 147-58

Parakkasi, I., \& Kamiruddin, K. (2018). Analisis Harga Dan Mekanisme Pasar Dalam Perspektif Islam. Laa Maisyir: Jurnal Ekonomi Islam, 5(1). 